24 Brook RG, Jendleg S, Lindgren B, Persson U, Bjork S. Euroqol: health related quality of life measurement. Results of the Swedish questionnaire exercise. Health Policy 1991;18:37-48.

25 Keeney RL, Raiffa H. Decisions with multiple objectives: preferences and value trade-offs. New York: Wiley, 1976.

26 Grimley-Evans J. Quality-of-life assessments and elderly people. In: Hopkins A, ed. Measures of the quality-of-life. London: Royal College of Physicians, A, ed. Measur

27 Kristiansen IS, Eggen AE, Thelle DS. Cost effectiveness of incremental programmes for lowering serum cholesterol concentration: is individual intervention worthwhile? BMf 1991;302:1119-22.

28 Discounting health care: only a matter of timing? Lancet 1992;340:148-9.

29 Parsonage M, Neuberger H. Discounting and health benefits. Health Economics 1992;1:71-6.

30 Cairns J. Discounting and health benefits: another perspective. Health Economics 1992;1:76-9.

31 Office of Population Censuses and Surveys. English life tables. No 14. London: HMSO, 1987.
32 Normand C. Economics, health, and the economics of health. BMf 1991; 303:1572-7.

3 Cox DR, Fitzpatrick R, Fletcher AE, Gore SM, Spiegelhalter DJ, Jones DR Quality-of-life assessment: can we keep it simple? fournal of the Royal Quatistical Society Series A 1992;155:353-93.

34 Dowie J. The ethics of allocating health resources. Sydney: New South Wales Health Department, 1991. (State Health Publication No (HPA)91-58.)

35 Buxton MJ. Are we satisfied with QALYs? In: Hopkins A, ed. Measures of the quality-of-life. London: Royal College of Physicians, 1992:41-9.

36 Wagstaff A. QALYs and the equity-efficiency trade-off. Journal of Health Economics 1991;5:1-30.

37 Drummond MF. Resource allocation decisions in health care: a role for quality of life assessments? F Chron Dis 1987;40:605-16.

38 Boyle MH, Torrance GW, Sinclair JC, Sargent PH. Economic evaluation of neonatal intensive care of very-low-birth-weight infants. $N$ Engl $f \mathrm{Med}$ 1983;308:1330-7.

(Accepted 9 September 1992)

\title{
Reforming the Department of Health's research and development policy: from the devil to the deep blue sea?
}

\author{
Alan Maynard, Trevor Sheldon
}

\begin{abstract}
Summary
Research into health and social services in Britain is largely funded by the Department of Health. Regional NHS research and development has recently been reformed and a new report now proposes replacement of the 13 research units funded by the department with three or four large multidisciplinary centres. Evidence to support such a step is lacking, and many criticisms of the existing units arise from poor departmental planning rather than deficiencies of the units themselves. Large units may make research less responsive to the department's needs, and it is essential that the proposed new structure is thoroughly evaluated before it is introduced.
\end{abstract}

Since the reform of the Department of Health's research and development division and the appointment of Professor Michael Peckham as its director, the profile of health and health care research has improved inside and outside the department. This development has been assisted by a demand for knowledge about "what works" in health care by purchasers and providers, who are required to deliver demonstrably cost effective care to patients in the newly reformed NHS.

The evolving reforms of the department's research and development policy, like the NHS reforms themselves, are bold, radical, and unproved. Careful consideration of their potential effectiveness is essential and it is important to proceed carefully and evaluate systematically.

The research and development policy announced in $1991^{1}$ created 14 regional bureaucracies to manage the existing and largely inadequate regional research functions. This structure is nearing completion. It is consuming considerable sums in management and may focus research activity and funding more effectively on NHS policy needs. The case for piloting and evaluating such a structure was, as with the case of the NHS reforms, rejected even though no evidence existed to support the structure and the merits of a unitary national institute of health, on the American model, were considerable and extensively explored in various forums. ${ }^{2}$

\section{Proposed abolition of research units}

Following the reform of regional NHS research and development it is proposed that the 13 research units funded by the Department of Health are abolished. ${ }^{34}$

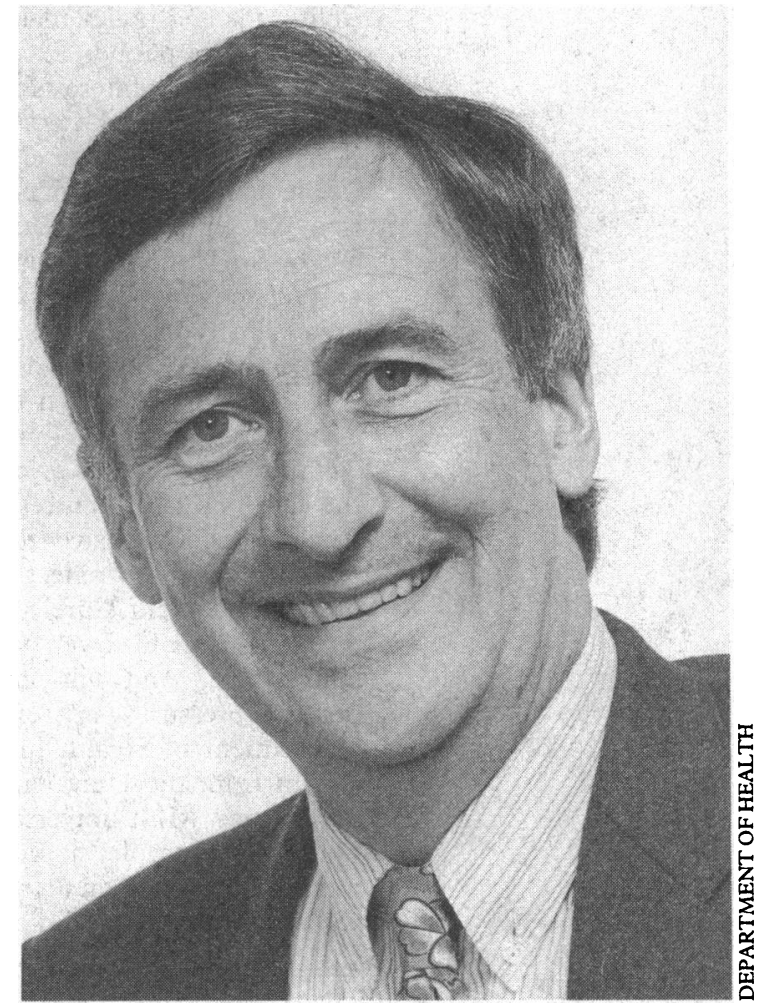

Professor Michael Peckham has raised the profile of health service research

The department commissions over $30 \%$ of noncommercially funded research into health and persona social services in England. The units currently receive f6m, one third of the research and development division's budget. They are as diverse as Oxford's National Perinatal Epidemiology Unit, the York Centre for Health Economics, the Thomas Coram research unit, and the Childhood Cancer Research Unit.

These units may be replaced by three to four multidisciplinary centres chosen by competitive bidding. As 10 of the 13 units currently receive over $60 \%$ of their funding from the Department of Health this will mean the closure or severe contraction of nationally and in some cases internationally renowned units which form an important element of the limited health and social service research infrastructure.

Why change? The authors of the report argue that the 13 units cover too wide a field, that there is a danger of isolation and a need for greater collaboration, that 
they lack a cohesive framework and strategic planning, and that they have inadequately disseminated findings. ${ }^{3}$ The report fails to substantiate many of these claims and fails to recognise that to the extent they exist, they could be remedied by better management of the Department of Health and the units. The review concludes that the number and spread of the existing units is too wide and the disciplinary composition too narrow to meet the requirements of the new research and development strategy. ${ }^{1}$ No analysis or illustration of how the strategy would be better served by the proposed changes is given.

\section{Would fewer centres improve the focus?}

The criticisms of the lack of focus and strategy and poor dissemination of results may be correct in many cases but should be aimed at the research customers (the Department of Health) and not the units. During the 1980 s planning was unfashionable and policy zigzagged, with research funding oscillating in response. Proposals for longer term work put to the department were often turned down because they did not correspond to the latest short term perceived need of politicians and policy makers, who were often in their jobs for short periods. Units therefore had to maintain a broad range of interests to have the flexibility to meet policy changes and customer's needs. This is not a function of the size or competence of the units but a reflection of the lack of coherent policy and coordination of departmental research, as pointed out four years ago by the House of Lords select committee on science and technology. ${ }^{2}$ The spread of interests across the 13 units helped diversify the research base in the country, protecting it from policy oscillations.

The concentration on three or four grand centres, even more dependent on the departmental funding, will not solve this. No evidence is advanced to support the case that large centres would be more productive, flexible, or responsive than smaller ones, and the proposal seems to reflect current fashion rather than rational judgment. Surely it is risky for the department to put its eggs in fewer baskets. Are such institutions manageable? And will not fewer units reduce competitive pressures in research funding? $£ 1.5 \mathrm{~m}$ of Department of Health funding is to be matched by $£ 1.5 \mathrm{~m}$ from the University Funding Council in host universities. Most universities, except those with trust funds (for example, in London), could not afford to participate in such an activity. Non-clinical research is surely cheaper than clinical research. Or is the $£ 3 \mathrm{~m}$ budget a reflection of the reviewers' preference for purely clinical units and a contradiction of other views expressed in their report? The advantages to the department of such units is not obvious and poorly articulated in the review. Large centres might be less responsive to departmental needs and the research topics chosen, which reflect current unsubstantiated fashions, may lose relevance quickly and leave departmental resources locked into work of limited importance.

As the authors of the review and others agree, much research into health and personal social service is best done by collaboration across disciplines. ${ }^{5}$ However, because health services research is not a discipline, units with a "lead" discipline and a strong disciplinary base may have greater intellectual coherence and anchorage to carry out quality work, calling on colleagues from other disciplines to collaborate on different projects. The fact that a unit has a core discipline does not preclude multidisciplinary collaboration and networking. To insist that all research and development centres funded by the Department of Health be multidisciplinary is again a statement of faith not supported by evidence. Diversity might be a shrewder policy. Disbanding units with strong disciplinary elements in favour of a few large and homogeneous generic centres where researchers might feel isolated from their main disciplines could deprive the NHS of a rich variety of interests and approaches.

The development of an effective research and development strategy in the department and the NHS is supported by the research community. The proposals of the review team are incomplete and require careful consideration. It would be unfortunate if, as a result of this report, some teams of experienced and productive researchers were disbanded on the basis of generalisations and replaced precipitously by unproved structures that may serve the department and the NHS less well. Before the devil you know is abandoned, the rocks in the deep blue sea of the new structure should be charted and evaluated carefully.

\footnotetext{
1 Department of Health. Research for health-a research and development strategy for the NHS. London: $\mathrm{DoH}, 1991$

2 House of Lords Select Committee on Science and Technology. Priorities in medical research. Vol 1. London: HMSO, 1988.
.

3 Williams PO (chair). Review of the role of DoH funded research units. Report to the director of research and development of a review team. London: Department of Health, 1992.

4 Delamothe T. New structures recommended for DoH funded research. BMF 1992;305:1117.

5 Clarke M, Kurinczuk JJ. Health services research: a case of need or special
} pleading? BMF 1992;304:1675-6

\section{ANY QUESTIONS}

Some patients with hypothyroidism seem to benefit from being given triiodothyronine and thyroxine rather than thyroxine alone. Is there any explanation for this?

The main source of circulating triiodothyronine in normal patients is peripheral tissue deiodination of thyroxine. Before the importance of this conversion was fully understood it was suggested that triiodothyronine, given alone or in combination with thyroxine, might be more beneficial than thyroxine alone in treating hypothyroidism. In support of this are the observations that triiodothyronine is the active hormone, is more potent weight for weight, and acts more rapidly than thyroxine when given by mouth. Much of the intracellular triiodothyronine, however, is derived from intracellular conversion of thyroxine to triiodothyronine, which depends on the serum thyroxine concentration. In addition the percentage of intracellular triiodothyronine derived from thyroxine is tissue specific. Thus the heart and kidney derive less than a fifth of triiodothyronine from circulating thyroxine, whereas roughly half of triiodothyronine in the anterior pituitary gland derives from thyroxine in the circulation. ${ }^{1}$ It has been argued convincingly therefore that thyroxine is the most appropriate treatment for hypothyroidism; this results in a continuous source of tissue and plasma triiodothyronine through deiodination and more closely resembles what happens in euthyroid subjects. Furthermore, triiodothyronine must be given two or three times a day because of a short plasma half life, unlike thyroxine, which can be given as a single daily dose, and considerable fluctuations in serum triiodothyronine concentrations occur after oral ingestion. There is no evidence that use of triiodothyronine has any clinical advantage over use of thyroxine, and thus triiodothyronine treatment cannot be recommended. - M C SHEPPARD, professor of medicine, Birmingham

1 Larsen PR, Silva JE, Kaplan MM. Relationships between circulating and intracellular thyroid hormones: physiological and clinic implications. Endocrinol Rev 1981;2:87-102. 